\title{
Pemeriksaan Kesehatan dan Terapi Komplementer di Kelurahan Murni Kecamatan Danau Sipin Kota Jambi
}

\author{
Fithriyani $^{1}$, Rahmi Dwi Yanti ${ }^{2}$ \\ ${ }^{1}$ Program Studi S1 keperawatan, STIKes Baiturrahim Jambi \\ ${ }^{2}$ Program Studi S1 keperawatan, STIKes Baiturrahim Jambi \\ Email: fithri.yani25@yahoo.co.id
}

Submitted : 03/09/2020

Accepted: 27/09/2020

Published: 11/01/2021

\begin{abstract}
Age, poverty and lack of knowledge about the use of health services are a combination of risk factors that can make their health more vulnerable. The area of Murni Village, Danau Sipin District, Jambi City, 50.28\% of the community is the stage of adulthood, namely 19-55 years. From these data, it is detected that they have a history of hypertension, rheumatism, diabetes mellitus and gastritis, but the exact incidence cannot be estimated. distribution of these health problems, it is necessary to carry out routine and specific health checks so that health problems can be detected in the pure village residents. The target of this activity is the elderly in RT 3, Murni, namely by conducting health examination activities which include measurement of blood pressure, blood sugar, and BMI as well as socialization of complementary therapy to cadres and local residents. Based on the results of blood pressure checks obtained from 35 people, 37\% (13) people with high blood pressure and 22 (63\%) people with blood pressure within normal limits. Examination of high blood sugar 2 (6\%), 32 (91\%) normal and 1 (3\%) with low blood sugar. The status of blood pressure in the community in RT 03 Kelurahan Murni is a small part with high blood pressure and the status of blood sugar levels in the community in RT 03 Kelurahan Murni is mostly with normal blood sugar.
\end{abstract}

Keywords: blood pressure, blood sugar, complementary

\begin{abstract}
Abstrak
Usia, kemiskinan dan kurangnya pengetahuan tentang pemanfaatan pelayanan kesehatan merupakan kombinasi factor resiko yang dapat menjadi semakin rentan dengan kesehatannya. Wilayah kelurahan Murni Kecamaan Danau Sipin Kota Jambi, terhadap masyarakat 50,28\% merupakan tahapan usia dewasa yaitu 19-55 tahun. Dari data tersebut yang terdeteksi memiliki riwayat hipertensi, rematik, diabetes mellitus dan gastritis,namun belum bisa diperkirakan angka kejadian pastinya. distribusi permasalahan kesehatan tersebut maka perlu dilakukannya pemeriksaan kesehatan secara rutin dan spesifik sehingga terdeteksinya permasalahan kesehatan warga di kelurahan murni. Target kegiatan ini adalah lansia di RT 3 Kelurahan Murni yaitu dengan melakukan Kegiatan pemeriksaan kesehatan yang meliputi Pengukuran tekanan darah, gula darah, dan IMT serta Sosialisasi mengenai terapi komplementer kepada kader dan warga setempat. Berdasarkan hasil pemeriksaan tekanan darah didapatkan dari 35 orang, 37\% (13) orang dengan tekanan darah tinggi dan $22(63 \%)$ orang dengan tekanan darah dalam batas normal. Pemeriksaan gula darah tinggi $2(6 \%), 32(91 \%)$ normal dan $1(3 \%)$ dengan gula darah rendah. Status tekanan darah pada masyarakat di RT 03 Kelurahan Murni sebagian kecil dengan tekanan darah tinggi dan Status kadar gula darah sewaktu pada masyarakat di RT 03 Kelurahan Murni sebagain besar dengan gula darah normal.
\end{abstract}

Kata kunci: gula darah, komplementer, tekanan darah 


\section{PENDAHULUAN}

Usia, kemiskinan dan kurangnya pengetahuan tentang pemanfaatan pelayanan kesehatan merupakan kombinasi factor resiko yang dapat menjadi semakin rentan dengan kesehatannya. Berdasarkan situasi tersebut maka perlu dilakukan upaya skrining kesehatan yang melibatkan beberapa lembaga seperti peran kader, Kepala desa, tokoh masyarakat dan agama untuk dilaksanakan upaya pemeriksaan kesehatan dan terapi komplementer guna meningkatkan taraf kesehatan yang optimal dan penurunan angka kesakitan khususnya bagi masyarakat yang kurang mampu. Kegiatan ini dilaksanakan sebagai wujud kepedulian kami sebagai tenaga kesehatan untuk meningkatkan derajat kesehatan masyarakat.

Riskesdas (2018) melaporkan bahwa prevalensi penyakit sendi pada penduduk umur $\geq 15$ tahun di Indonesia pada tahun 2013 berada pada angka 11,9\% dan terjadi penurunan di tahun 2018 di angka 7,3\%. Sedangkan di Provinsi Jambi angka penyakit sendi mengalami peningkatan yaitu sekitar 8,2\% ditahun 2013 menjadi 9\% di tahun 2018.

Wilayah kelurahan Murni Kecamatan Danau Sipin Kota Jambi, terhadap masyarakat $50,28 \%$ merupakan tahapan usia dewasa yaitu 19-55 tahun. Dari data tersebut yang terdeteksi memiliki riwayat hipertensi, rematik, diabetes mellitus dan gastritis, namun belum bisa diperkirakan angka kejadian pastinya. Belum terdeteksinya kondisi kesehatan masyarakat dapat disebabkan karena belum optimalnya pelayanan yang ada di Posyandu Lansia, faktor ekonomi masyarakat yang menyebabkan minimnya pemanfaatan pelayanan kesehatan.

\section{TARGET DAN LUARAN}

1) Target

Target kegiatan ini adalah lansia di RT

3 Kelurahan yang faktor pengetahuan yang kurang terhadap gaya hidup yang baik dan penanganan masalah kesehatan bersumberdaya komplementer dan Penurunan derajat kesehatan terhadap masyarakat khususnya lansia dan dewasa.

2) Luaran

Luaran kegiatan ini Implementasi kegiatan pemeriksaan kesehatan yang meliputi Pengukuran tekanan darah, gula darah, kadar asam urat dan IMT dan peningkatan pengetahuan masyarakat melalui Sosialisasi terapi komplementer kepada kader dan warga setempat.

\section{METODE PELAKSANAAN}

1. Waktu dan tempat

Kegiatan dilaksanakan pada tanggal 1 Agustus 2019 di Rumah Ketua RT 03 Kelurahan Murni

\section{Sasaran}

Sasaran kegiatan adalah warga RT 03 Kelurahan Murni yang memiliki riwayat hipertensi, asam urat, DM

3. Bentuk kegiatan berupa:

a. Sosialisasi mengenai terapi komplementer kepada kader dan warga setempat melalui penyebaran leflat

b. Kegiatan pemeriksaan kesehatan yang meliputi Pengukuran tekanan darah, gula darah, dan IMT.

Metode penatalaksanaan

pemeriksaan kesehatan menggunakan metode 5 meja, yang terdiri dari: meja pertama untuk pendaftaran, meja kedua untuk pengukuran/pemeriksaan, meja ketiga untuk pencatatan hasil, meja ke empat dan ke lima untuk penyuluhan atau konsultasi.

Alat atau instrumen yang digunakan dalam kegiatan diantaranya : Set pemeriksaan gula darah: 6 unit, Set Pemeriksaan tekanan darah (Stetoscope, spygmomanometer) : 6 unit, Alat pengukuran berat badan dan tinggi badan 


\section{HASIL DAN PEMBAHASAN}

\section{A. Persiapan kegiatan}

1. Persiapan awal kegiatan melakukan koordinasi dengan Puskesmas Putri Ayu tentang rencana kegiatan dalam upaya penanganan masalah kesehatan yang ada di RT 3 Kelurahan Murni

2. Mensosialisasikan dan menginformasikan ke warga mengenai rencana kegiatan melalui penyebaran leflat, undangan dan melalui TOA masjid setempat dibantu oleh kader setempat.

B. Pelaksanaan kegiatan

Kegiatan dilakukan dalam 1 hari meliputi dengan prosedur peserta mengisi daftar hadir dan dilakukan pengukuran IMT yaitu Tinggi dan Berat badan, kemudian diarahkan kemeja pemeriksaan kesehatan antara lain pemeriksaan tekanan darah dan gula darah, setelah selesai pemeriksaan peserta diberikan informasi tentang terapi komplementer dalam meningkatkan kesehatan dalam kehidupan seharihari.

Distribusi frekuensi berdasarkan pengukuran tekanan darah hasil pemeriksaan kesehatan didapatkan sebagai berikut:

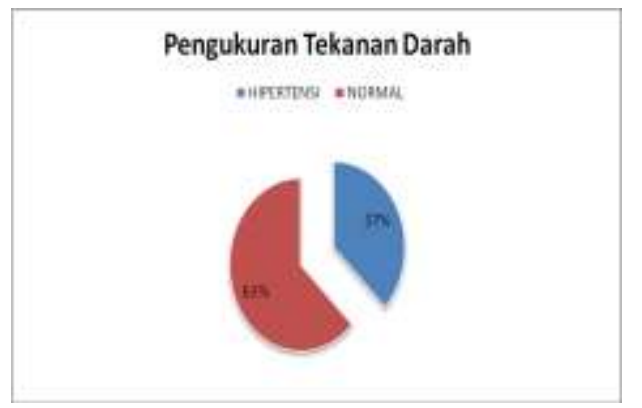

Diagram 1. Hasil pengukuran tekanan darah

Berdasarkan hasil pemeriksaan tekanan darah didapatkan dari 35 orang, $37 \%$ (13) orang dengan tekanan darah tinggi dan $22(63 \%)$ orang dengan tekanan darah dalam batas normal.
Tekanan darah tinggi dapat berkaitan dengan faktor usia, gaya hidup, genetik dan karena penyakit sekunder lainnya. Tekanan darah tinggi pada lansia dapat berpotensi menimbulkan berbagai masalah kesehatan seperti penyakit jantung, maupun stroke. Faktor yang berperan terjadinya hipertensi pada usia lanjut adalah peningkatan sensitivitas terhadap asupan natrium, penurunan elastisitas pembuluh darah perifer yang diakibatkan oleh proses menua sehingga akan mengakibatkan tekanan darah akan meningkat (Martono, 2006). Upaya antisipasi tingginya tekanan darah pada lansia menurut Nursing Intervention clarification dengan modifikasi terapi alternative yaitu dengan perubahan gaya hidup maupun pemanfaatan tanaman herbal sebagai terapi komplementer pada lansia. Terapi komplementer yang diberikan seperti terapi pemberian mix jus belimbing dan timun, daun seledri.

Distribusi Frekuensi Berdasarkan Pemeriksaan Gula Darah didapatkan sebagai berikut:

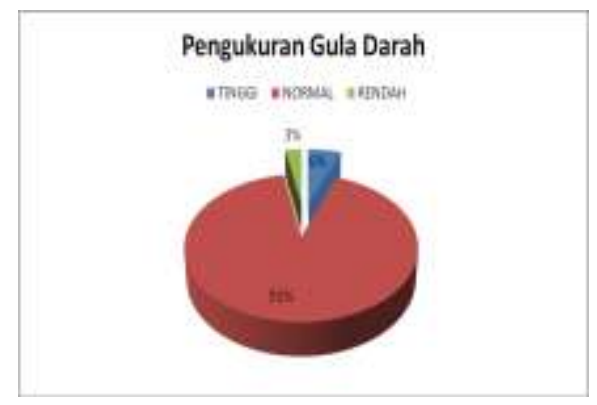

Diagram 2. Hasil pengukuran Gula Darah

Berdasarkan hasil diagram diatas didapatkan bahwa gula darah tinggi $2(6 \%)$, $32(91 \%)$ normal dan $1(3 \%)$ dengan gula darah rendah. Tingginya kadar gula darah pada lansia dalam diagnose medis disebut dengan penyakit Diabetes Melitus. Diabetes Melitus adalah penyakit metabolik yang kebanyakan herediter, dengan tanda - tanda hiperglikemia dan glukosuria, disertai dengan atau tidak adanya gejala klinik akut ataupun kronik, sebagai akibat dari 
kuranganya insulin efektif di dalam tubuh, gangguan primer terletak pada metabolisme karbohidrat yang biasanya disertai juga gangguan metabolisme lemak dan protein ( Askandar, 2000).

Diabetes mellitus saat ini merupakan penyakit yang banyak dijumpai dengan prevalensi di seluruh dunia sebanyak $4 \%$. Prevalensinya akan terus meningkat dan diperkirakan akan mencapai $5,4 \%$ pada tahun 2025. Di Indonesia meskipun belum ada data yang resmi, tetapi diperkirakan prevalensinya akan terus meningkat. Kadar glukosa darah dipengaruhi oleh faktor endogen dan eksogen. Faktor endogen yaitu humoral factor seperti hormon insulin, glukagon, kortisol; system reseptor di otot dan sel hati. Faktor eksogen antara lain jenis dan jumlah makanan yang dikonsumsi serta aktivitas fisik yang dilakukan. Seiring arus globalisasi menyebabkan terjadinya perubahan pola hidup yang cenderung mengacu pada gaya hidup tidak sehat. Konsumsi makanan siap saji (junk food) dan makanan instan semakin meningkat di kalangan masyarakat Indonesia terutama pada daerah-daerah yang mengalami akulturasi. Selain itu, karena terjadinya peningkatan kesibukan kerja menyebabkan adanya kecenderungan untuk mengurangi aktivitas fisik seperti olah raga. Perubahan pola hidup ini tidak hanya dapat kita jumpai pada masyarakat perkotaan saja tetapi sudah mulai merambah ke daerah pinggiran kota yang merupakan masyarakat semiurban. Kurangnya kesadaran masyarakat akan kesehatan dapat memperburuk kondisi kesehatan mereka dan memicu terjadinya berbagai penyakit kronis seperti DM.

Selama ini diagnosis DM hanya diperoleh dari masyarakat/ pasien yang datang ke pusat-pusat kesehatan seperti puskesmas atau rumah sakit. Upaya deteksi dini terhadap penyakit ini seperti skrining kadar gula darah belum pernah dilakukan. Perlunya deteksi dini dilakukan adalah untuk pengendalian dan mencegah terjadinya komplikasi. Menyadari hal ini, deteksi dini terhadap penyakitpenyakit kronis seperti DM sangat perlu dilakukan terhadap masyarakat yang mempunyai faktor risiko baik karena pola hidup tidak sehat dan faktor keturunan. Deteksi dini terhadap DM dapat dilakukan melalui skrining dengan pemeriksaan kadar gula darah sewaktu. Selain itu, keberhasilan dalam pencegahan timbulnya DM dan pengendalian kadar gula darah pada penderita DM tergantung pada prilaku masyarakat.

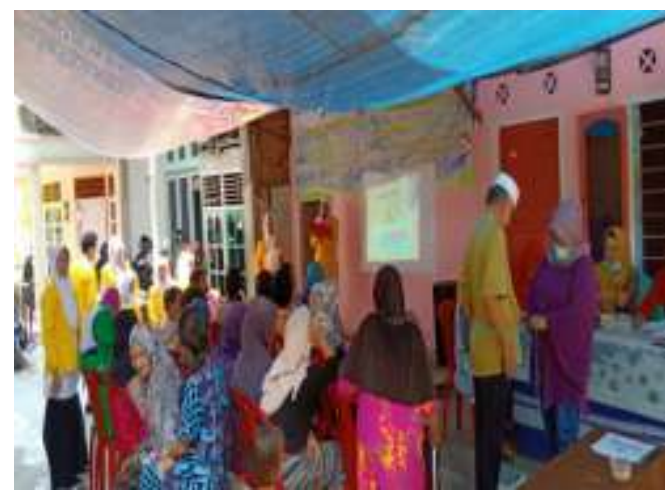

Gambar 1. Kegiatan Pemeriksaan Tekanan darag,Gua darah dan IMT

\section{KESIMPULAN DAN SARAN}

\section{Kesimpulan}

Status tekanan darah pada masyarakat di RT 03 Kelurahan Murni sebagian kecil dengan tekanan darah tinggi dan Status kadar gula darah sewaktu sebagain besar dengan gula darah normal. Namun dengan banyaknya lansia di wilayah tersebut, perlunya antispiasi pencegahan penyakit hipertensi dan gula darah dengan memperhatikan pola hidup dan penanganan yang tepat.

\section{Saran}

Kepala Puskesmas perlu memberikan support untuk perawat pengelola Perkesmas untuk melakukan home visite guna perawatan lanjutan bagi lansia yang mengalami keterbatasan dalam melakukan pemeriksaan di pelayanan Puskesmas 


\section{UCAPAN TERIMAKASIH}

Ucapan terimakasih kepada ketua Rt 03 dan kader kelurahan Murni yang telah menfasilitasi kegiatan ini sampai selesai dan kepada Stikes baiturahim Jambi yang telah mendanai kegiatan pengabdian ini.

\section{DAFTAR PUSTAKA}

Askandar.2001. Penanganan ganggren pada penderita DM

KEMENKES RI, 2013. Batasan umur lansia menurut Undang-Undang Nomor 13 Tahun 1998 tentang kesejahteraan lansia menyatakan bahwa batasan umur lansia di Indonesia adalah 60 tahun keatas.

WHO .2016. Batasan usia lansia

Stanley \& Beare. .2006. Buku Ajar Keperawatan Gerontik. Jakarta : EGC

Suwarsi. 2016. Pemeriksaan kesehatan dan terapi komplementer di desa Wedomartani Sleman Padukuhan Tonggalan. Jurnal keperawatan respati yogyakarta, 3 (2), september 2016, 1-5 